\section{In-Hospital Mortality and Complications Following Coronary Artery Bypass Surgery; is it Possible to Predict with Preoperative Values?}

\author{
Koroner Arter Baypas Cerrahisi Sonrası Gelişen \\ Hastane İci Mortalite ve Komplikasyonlar, \\ Preoperatif Değerlerle Prediksiyon Mümkün mü?
}

Eda Balcı (1)

Aslıhan Aykut (D)

Aslı Demir (1)

Ülkü Sabuncu (1)

Rabia Koçulu (1)

Ümit Karadeniz (

\begin{abstract}
Objective: The aim of this study is to evaluate short-term complications and mortality in patients undergoing isolated coronary artery bypass surgery with preoperative predictors commonly used in the literature.

Methods: A total of 518 patients who underwent coronary artery bypass surgery using cardiopulmonary bypass pump were retrospectively investigated. Preoperative fasting blood glucose, hemoglobin, neutrophil, platelet count, erythrocyte distribution width, mean platelet volume, platelet lymphocyte ratio, neutrophil lymphocyte ratio, metabolic syndrome criteria were recorded. These preoperative data have been investigated in relation to postoperative short term complications and mortality.

Results: Twenty-six (5\%) out of 518 patients exited within postoperative 30 days. Mortality was associated with advanced age, presence of hypertension, fasting blood glucose and platelet lymphocyte ratio. However, in multivariate analyzes, only advanced age was seen as an independent predictor of mortality. At least one postoperative complication was seen in 66 (12.7\%) patients. Age, fasting blood glucose, hemoglobin value, mean platelet volume, neutrophil lymphocyte ratio were found to be associated with the development of complications. However, in multivariate analyzes only age was seen as independent predictor of development of complications.

Conclusion: It is not possible to predict mortality and complications in patients undergoing coronary artery bypass surgery using only preoperative data.
\end{abstract}

Keywords: Coronary artery bypass surgery, complications, mortality, preoperative predictors

Öz

Amaç: Bu çalışmanın amacı, izole koroner arter baypas cerrahisi geçiren hastalardaki, kısa dönemde gelişen komplikasyon ve mortalitenin, literatürde sık kullanılan preoperatif prediktörler ile değerlendirilmesidir.

Yöntem: Kardiyopulmoner baypas pompası kullanılarak koroner arter baypas cerrahisi yapılan 518 hasta retrospektif olarak araştırılmışır. Preoperatif açık kan glukozu, hemoglobin, nötrofil, platelet sayısı, eritrosit dağılım genişliği, ortalama platelet hacmi, platelet lenfosit oranı, nötrofil lenfosit oranı, metabolik sendrom kriterleri kaydedilmiştir. Bu preoperatif verilerin postoperatif kısa dönem komplikasyonlar ve mortalite ile ilișkisi araștırılmıştır.

Bulgular: 518 hastanın 26'sında (\%5) 30-günlük mortalite gözlenmişsir. Mortalite ile ileri yaş, hipertansiyon varlığı, açlık kan glukozu ve platelet lenfosit oranı ilişkili bulunmuştur. Ancak, çok değişkenli analizlerde yalnızca ileri yaşın mortalite için bağımsız prediktör olduğu görülmüştür. Hastaların 66'sında $(\% 12,7)$ postoperatif en az bir komplikasyon görülmüştür. Yaş, açlık kan glukozu, hemoglobin değeri, ortalama platelet hacmi, nötrofil lenfosit oranı komplikasyon gelişimi ile lişkili bulunmuştur. Ancak çok değişkenli analizlerde yalnızca ileri yaş komplikasyon gelişimi için bağımsız prediktör olarak görülmüştür.

Sonuç: Yalnızca preoperatif veriler ile koroner arter baypas cerrahisi geçiren hastalarda mortalite ve komplikasyon öngörmek olası değildir.

Anahtar kelimeler: Koroner arter baypas cerrahisi, komplikasyon, mortalite, preoperatif prediktörler
Alındığı tarih: 24.10 .2018
Kabul tarihi: 12.12 .2018
Yayın tarihi: 31.01 .2019

Eda Balcı Kızılay Sokak No:4 06100 Sihhiye Ankara, Türkiye edaaksoy84@gmail.com ORCID: 0000-0002-8113-4080

A. Aykut 0000-0003-0382-3494

A. Demir 0000-0003-3053-0443

Ü. Sabuncu 0000-0002-9031-2088

R. Koçulu 0000-0001-9668-6737

Ü. Karadeniz 0000-0002-0067-6938

Türkiye Yüksek ihtisas Eğitim ve Araştirma Hastanesi, Anesteziyoloji ve Reanimasyon Kliniği, Ankara, Türkiye 
E. Balcı ve ark., In-Hospital Mortality and Complications Following Coronary Artery Bypass Surgery; is it Possible to Predict with Preoperative Values?

\section{INTRODUCTION}

The 30-days mortality rate after cardiac surgery is reported to be $1-4 \%$ in large studies of cardiac surgery ${ }^{(1)}$. According to the Society of Thoracic Surgeons (STS) the mortality rate for isolated coronary artery bypass surgery (CABG) is $2.3 \%$, and $3.4 \%$ for valve surgery ${ }^{(2,3)}$. The term "early mortality" defines mortality 30 days after cardiac surgery. Mortality and morbidity risks of the patients are evaluated by many scoring systems on preoperative period. The aim of preoperative evaluation in cardiac surgery is to reveal the severity of the disease, to determine the surgical risk, to optimize the patient before surgery and to take measures to reduce the risk of perioperative complications. With a better understanding of these risks, it is aimed to prevent possible complications, to increase life expectancy and quality after surgery, to shorten the length of intensive care and hospital stay and to reduce the hospital cost.

In the literature, many preoperative parameters have been investigated in order to estimate mortality and development of complication after cardiac surgery by simple and easy methods instead of detailed scoring systems. In this study, we aimed to evaluate the patients who died, and developed complications in the short term after isolated coronary artery bypass surgery in terms of simple preoperative predictors used frequently in the literature.

\section{MATERIAL and METHODS}

Following the approval of the hospital board for our retrospective cross-sectional study (date: 09.08.2018, number: 8802), 518 patients who underwent isolated coronary artery bypass grafting surgery using cardiopulmonary bypass (CPB) in 2018 were retrospectively investigated. Pediatric patients, patients who had undergone valve surgeries, aortic and other vascular surgeries, combined surgeries, off-pump surgeries, heart transplantation and surgeries for the implantation of ventricular support devices were not included in the study. Preoperative and postoperative data of these patients were obtained by scanning the files from hospital electronic database and archives. In addition to demographic information, preoperative fasting blood glucose, and hemoglobin values, neutrophil and platelet counts, red cell distribution width (RDW), mean platelet volume (MPV), platelet lymphocyte ratio (PLR) and neutrophil lymphocyte ratio (NLR) were recorded. Patients with at least 3 or more criteria were separated according to the criteria of metabolic syndrome (MS).

Diagnostic criteria of metabolic syndrome;

- Abdominal obesity (BMI $\geq 30 \mathrm{~kg} \mathrm{~m}^{-2}$ or waist circumference in women $\geq 80 \mathrm{~cm}$, in men $\geq 94 \mathrm{~cm}$ )

- Triglyceride $\geq 150 \mathrm{mg} \mathrm{dL}^{-1}$

- Fasting blood glucose $\geq 100 \mathrm{mg} \mathrm{dL}^{-1}$, or being under the treatment of diabetes mellitus

- Blood pressure $\geq 130 / 85 \mathrm{mmHg}$, or being under the treatment of Hypertension

- HDL level in men $<40 \mathrm{mg} \mathrm{dL}^{-1}$, in women $<50 \mathrm{mg}$ $\mathrm{dL}^{-1}$

*BMI (body mass index), HDL (high density lipoprotein)

Only isolated CABG surgery were included in the study in order to reach the right conclusion in terms of metabolic syndrome. Major complications in the postoperative period were classified as; cardiac, pulmonary, renal, cerebral, mediastinitis, revision surgery related with bleeding or tamponade. Cardiac complications, called as "major adverse cardiac events" (MACE); coronary artery stenting, nonfatal myocardial infarction, re-CABG, any cause of cardiac death were evaluated. Respiratory failure was defined as the need for postoperative mechanical ventilator support, which lasts more than 72 hours. Indication for dialysis or $\geq 1 \mathrm{mg} \mathrm{dL}^{-1}$ in postoperative serum creatinine relative to baseline value was defined as acute renal failure (ARF). Stroke was defined as a new, temporary or permanent central neurological deficits after cardiac surgery. Mediastinitis was defined as a deep sternal wound infection ${ }^{(4)}$. All major and minor complications developed in the postoperative period were classified under "overall adverse events". Patients were grouped according to mortality and complications. The effects of preoperative predictors of mortality and complication on the methods described below in these groups were investigated.

\section{Statistical Analysis}

Normally distributed continuous variables were expressed as "mean values \pm standard deviation (SD)" or 
median values with the interquartile range if not normally distributed. Categorical variables were expressed as numbers and percentages. Demographic characteristics, perioperative variables and calculated values were compared using "independent samples t-test" or "Mann-Whitney-U test" for continuous variables and "chi-square test" or "Fisher's exact test" for categorical variables. Correlations were assessed using Pearson's correlation test. For the multivariate analysis, the possible factor identified with univariate analyses ( $p<0.10$ for the first model and $p<0.05$ for the second model) was further entered into the logistic regression analysis to determine independent predictors of adverse events and mortality. Hosmer-Lemeshow goodness of fit statistics were used to assess model fit. A p value $<0.05$ was considered statistically significant. All statistical analyses were performed using the SPSS statistical software (SPSS for Windows 15.0, Inc., Chicago, IL, USA).

\section{RESULTS}

A total of 518 patients who underwent isolated CABG surgery with CPB within 1 year were included in the study. Patients with and without mortality were compared according to their preoperative characteristics and laboratory data (Table I). Age, presence of hypertension, preoperative blood glucose level and preoperative PLR were found to be associated with mortality $(p<0.001, p=0.064, p=0.066$, $p=0.039$, respectively). However, multivariate analy-

Table II. Multivariate analysis to determine independent predictor of mortality (Model 1 and Model 2)

\begin{tabular}{lcccccc}
\hline & \multicolumn{3}{c}{ Model 1 } & \multicolumn{3}{c}{ Model 2 } \\
\hline & OR & $\mathbf{9 5 \% ~ C l}$ & P value & OR & 95\% Cl & P value \\
\hline Age (years) & 1.10 & $1.05-1.16$ & $<0.001$ & 1.11 & $1.05-1.16$ & $<0.001$ \\
HT & 1.79 & $0.74-4.37$ & 0.331 & - & - & - \\
Glucose & 0.97 & $0.89-1.05$ & 0.441 & - & - & - \\
& & & & & & \\
\hline
\end{tabular}

Table I. Preoperative characteristics and laboratory values of patients with and without mortality

\begin{tabular}{|c|c|c|c|c|c|c|c|}
\hline \multirow[b]{2}{*}{ Features } & \multicolumn{2}{|c|}{$\begin{array}{c}\text { Total } \\
n=518\end{array}$} & \multicolumn{2}{|c|}{$\begin{array}{c}\text { Mortality (-) } \\
n=492\end{array}$} & \multicolumn{2}{|c|}{$\begin{array}{l}\text { Mortality (+) } \\
\quad n=26\end{array}$} & \multirow[b]{2}{*}{$P$ value } \\
\hline & $\begin{array}{c}\text { Mean } \pm \text { SD } \\
\text { or } n(\%)\end{array}$ & Median (IQR) & $\begin{array}{c}\text { Mean } \pm \text { SD } \\
\text { or } n(\%)\end{array}$ & Median (IQR) & $\begin{array}{c}\text { Mean } \pm \text { SD } \\
\text { or } n(\%)\end{array}$ & Median (IQR) & \\
\hline Age (years) & $60.4 \pm 9.2$ & $60(53-68)$ & $60.0 \pm 9.1$ & $60(53-67)$ & $67.9 \pm 8.2$ & $69.5(62-74)$ & $<0.001$ \\
\hline Male gender & $416(80.3 \%)$ & & 397 (80.7\%) & & $19(73.1 \%)$ & & 0.341 \\
\hline Hypertension & 267 (51.5\%) & & 249 (50.6\%) & & $18(69.2 \%)$ & & 0.064 \\
\hline BMI & $28.3 \pm 4.3$ & $27.9(25.6-31.1)$ & $28.4 \pm 4.3$ & $28.1(25.6-31.1)$ & $27.1 \pm 4.5$ & $26.4(23.5-30.1)$ & 0.150 \\
\hline Metabolic syndrome & 266 (51.4\%) & & $250(50.8 \%)$ & & $16(61.5 \%)$ & & 0.286 \\
\hline Glucose & $134.8 \pm 67.8$ & 109 (94-154) & $134.5 \pm 68.7$ & 107.5 (94-152) & $141.5 \pm 47.8$ & 105 (105-179) & 0.066 \\
\hline Hemoglobin & $14.1 \pm 1.7$ & $14.3(13.2-15.2)$ & $14.1 \pm 1.7$ & $14.3(13.2-15.2)$ & $13.4 \pm 2.1$ & $13.9(12.4-15.0)$ & 0.178 \\
\hline Neutrophil & $5.5 \pm 2.1$ & $5.1(4.2-6.3)$ & $5.5 \pm 2.1$ & $5.1(4.2-6.3)$ & $5.5 \pm 2.3$ & $5.5(4.0-6.1)$ & 0.892 \\
\hline Platelet & $234.8 \pm 64.6$ & 227 (191-265) & $234.4 \pm 64.9$ & $228(192-264)$ & $241.6 \pm 78.7$ & 215 (181-281) & 0.894 \\
\hline RDW & $14.0 \pm 1.3$ & $13.8(13.2-14.4)$ & $14.0 \pm 1.3$ & $13.8(13.2-14.4)$ & $14.2 \pm 1.4$ & $13.8(13.4-14.3)$ & 0.463 \\
\hline MPV & $9.0 \pm 1.1$ & $8.9(8.2-9.7)$ & $9.0 \pm 1.1$ & $8.9(8.2-9.7)$ & $9.1 \pm 1.2$ & $9.0(8.4-9.7)$ & 0.573 \\
\hline PLR & $116.2 \pm 49.5$ & $108(84-134)$ & $115.6 \pm 49.8$ & 107 (84-134) & $128.2 \pm 41.1$ & $121.5(106-141)$ & 0.039 \\
\hline NLR & $2.8 \pm 2.4$ & $2.4(1.8-3.2)$ & $2.8 \pm 2.5$ & $2.4(1.8-3.2)$ & $2.9 \pm 1.1$ & $2.8(1.9-3.6)$ & 0.200 \\
\hline
\end{tabular}

N: Number of patients, BMI: Body mass index, RDW: Redcell distribution width, MPV: Mean platelet volume, PLR: Platelet lymphocytes ratio, NLR: Neutrophil lymphocyte ratio

Table III. Postoperative complications of patients with and without mortality

\begin{tabular}{|c|c|c|c|c|c|c|}
\hline \multirow[b]{2}{*}{ Features } & $\begin{array}{c}\text { Total } \\
\mathrm{N}=518\end{array}$ & \multicolumn{2}{|c|}{$\begin{array}{l}\text { Mortality (-) } \\
\mathrm{N}=492\end{array}$} & \multicolumn{2}{|c|}{$\begin{array}{l}\text { Mortality (+) } \\
\mathrm{N}=26\end{array}$} & \multirow[b]{2}{*}{$P$ value } \\
\hline & $\begin{array}{l}\text { Mean } \pm \text { SD Median (IQR) } \\
\text { or } n(\%)\end{array}$ & $\begin{array}{l}\text { Mean } \pm \text { SD } \\
\text { or } n(\%)\end{array}$ & Median (IQR) & $\begin{array}{l}\text { Mean } \pm \text { SD } \\
\text { or } n(\%)\end{array}$ & Median (IQR) & \\
\hline MACE & $33(6.4 \%)$ & $9(1.8 \%)$ & & $24(92.3 \%)$ & & $<0.001$ \\
\hline Respiratory insuff & $12(2.3 \%)$ & $11(2.2 \%)$ & & $1(3.8 \%)$ & & 0.595 \\
\hline ARF & $9(1.7 \%)$ & $4(0.8 \%)$ & & $5(19.2 \%)$ & & $<0.001$ \\
\hline Stroke & $8(1.5 \%)$ & $8(1.6 \%)$ & & 0 & & 0.512 \\
\hline Mediastinitis & $11(2.1 \%)$ & $11(2.2 \%)$ & & 0 & & 0.441 \\
\hline Revision for bleeding/tamponade & $7(1.4 \%)$ & $5(1.0 \%)$ & & $2(7.7 \%)$ & & 0.004 \\
\hline Overall adverse events & $66(12.7 \%)$ & $40(8.1 \%)$ & & $26(100 \%)$ & & $<0.001$ \\
\hline
\end{tabular}

N: Number of patients, MACE: Major adverse cardiac events, ARF: Acute renal failure 
E. Balcı ve ark., In-Hospital Mortality and Complications Following Coronary Artery Bypass Surgery; is it Possible to Predict with Preoperative Values?

Tablo IV. Patients with mortality

\begin{tabular}{|c|c|c|c|}
\hline & Age/Sex & Complications & Mortality days \\
\hline 1. & $53 / \mathrm{M}$ & Bleeding/Tamponade & 2 \\
\hline 2. & $70 / F$ & MACE & 1 \\
\hline 3. & 61/M & MACE & 3 \\
\hline 4. & $75 / F$ & MACE & 1 \\
\hline 5. & $76 / F$ & MACE & 1 \\
\hline 6. & $72 / F$ & MACE & 3 \\
\hline 7. & 74/M & MACE & 3 \\
\hline 8. & 76/M & MACE,ARF & 20 \\
\hline 9. & 59/M & MACE & 1 \\
\hline 10. & $62 / M$ & MACE & 2 \\
\hline 11. & 73/M & MACE,ARF & 6 \\
\hline 12. & $69 / M$ & MACE & 1 \\
\hline 13. & 75/M & MACE,ARF & 5 \\
\hline 14. & $70 / F$ & MACE & 6 \\
\hline 15. & 74/M & MACE & 5 \\
\hline 16. & $69 / F$ & MACE & 1 \\
\hline 17. & $51 / F$ & MACE & 1 \\
\hline 18. & $58 / \mathrm{M}$ & MACE,ARF,bleeding/tamponade & 4 \\
\hline 19. & $75 / \mathrm{M}$ & MACE & 4 \\
\hline 20. & $51 / \mathrm{M}$ & Respiratory failure & 28 \\
\hline 21. & $67 / M$ & MACE,ARF & 30 \\
\hline 22. & 74/M & MACE & 2 \\
\hline 23. & $67 / M$ & MACE & 4 \\
\hline 24. & $68 / \mathrm{M}$ & MACE & 3 \\
\hline 25. & $81 / \mathrm{M}$ & MACE & 3 \\
\hline 26. & $66 / M$ & MACE & 4 \\
\hline
\end{tabular}

MACE: Major adverse cardiac events, ARF: Acute renal failure
Table VI. Multivariate analysis to determine independent predictor of adverse events (Model 1 and Model 2)

\begin{tabular}{lcccccc}
\hline & \multicolumn{3}{c}{ Model 1 } & \multicolumn{3}{c}{ Model 2 } \\
\hline & OR & 95\% Cl & P value & OR & 95\% Cl & P value \\
\hline Age (years) & 1.06 & $1.02-1.09$ & 0.001 & 1.05 & $1.02-1.09$ & 0.001 \\
Glucose & 1.00 & $1.00-1.01$ & 0.271 & 1.00 & $1.00-1.01$ & 0.271 \\
Hb & 0.87 & $0.75-1.01$ & 0.074 & 0.87 & $0.75-1.01$ & 0.074 \\
MPV & 1.19 & $0.95-1.50$ & 0.135 & - & - & - \\
NLR & 0.98 & $0.90-1.08$ & 0.732 & 0.99 & $0.90-1.08$ & 0.732
\end{tabular}

PLR: Platelet lymphocytes ratio, NLR: Neutrophil lymphocyte ratio

sis of these data with indicated models, showed that only age was an independent predictor of mortality $(p<0.001)$ (Table II). In Table III, patients who exited, and survived were compared according to postoperative complications. MACE $(p<0.001), \operatorname{ARF}(p<0.001)$, revision surgery related with bleeding/tamponade $(p=0.004)$ and overall adverse events $(p<0.001)$ were found to be statistically significant in relation to mortality. Twenty-six exited patients were listed according to age, sex, complications and date of death in Table IV. Major adverse cardiac events caused death

Table V. Characteristics of patients with and without adverse events

\begin{tabular}{|c|c|c|c|c|c|c|c|}
\hline \multirow[b]{2}{*}{ Features } & \multicolumn{2}{|c|}{$\begin{array}{c}\text { Total } \\
\mathrm{N}=518\end{array}$} & \multicolumn{2}{|c|}{$\begin{array}{c}\text { Adverse events (-) } \\
\quad \mathrm{N}=452\end{array}$} & \multicolumn{2}{|c|}{$\begin{array}{l}\text { Adverse events }(+) \\
\qquad \mathrm{N}=66\end{array}$} & \multirow[b]{2}{*}{$P$ value } \\
\hline & $\begin{array}{l}\text { Mean } \pm \text { SD } \\
\text { or } n(\%)\end{array}$ & Median (IQR) & $\begin{array}{l}\text { Mean } \pm \text { SD } \\
\text { or } n(\%)\end{array}$ & Median (IQR) & $\begin{array}{l}\text { Mean } \pm S D \\
\text { or } n(\%)\end{array}$ & Median (IQR) & \\
\hline Age (years) & $60.4 \pm 9.2$ & $60(53-68)$ & $59.9 \pm 9.1$ & $60(53-67)$ & $65.2 \pm 9.4$ & $66(59-71)$ & $<0.001$ \\
\hline Male gender & 416 (80.3\%) & & $363(80.3 \%)$ & & $53(80.3 \%)$ & & 0.999 \\
\hline Hypertension & 267 (51.5\%) & & $228(50.4 \%)$ & & 39 (59.1\%) & & 0.189 \\
\hline BMI & $28.3 \pm 4.3$ & $27.9(25.6-31.1)$ & $28.4 \pm 4.4$ & $28.1(25.6-31.1)$ & $27.9 \pm 3.9$ & $27.6(25.6-30.1)$ & 0.488 \\
\hline Metabolic syndrome & 266 (51.4\%) & & $228(50.4 \%)$ & & 38 (57.6\%) & & 0.279 \\
\hline Glucose & $134.8 \pm 67.8$ & 109 (94-154) & $133.4 \pm 68.5$ & 107 (94-152) & $144.9 \pm 62.9$ & 122 (96-179) & 0.046 \\
\hline Hemoglobin & $14.1 \pm 1.7$ & $14.3(13.2-15.2)$ & $14.2 \pm 1.6$ & $14.4(13.3-15.2)$ & $13.5 \pm 2.0$ & $13.7(12.4-14.7)$ & 0.005 \\
\hline LDL & $111.3 \pm 42.0$ & $107(80-137)$ & $111.5 \pm 41.3$ & $107(82-137)$ & $109.8 \pm 46.6$ & $103(77-136)$ & 0.465 \\
\hline Neutrophil & $5.5 \pm 2.1$ & $5.1(4.2-6.3)$ & $5.4 \pm 2.0$ & $5.0(4.1-6.3)$ & $6.0 \pm 2.5$ & $5.5(4.6-6.4)$ & 0.073 \\
\hline Platelet & $234.8 \pm 64.6$ & 227 (191-265) & $235.6 \pm 64.4$ & 230 (191.5-265) & $229.2 \pm 66.5$ & 212 (191-255) & 0.199 \\
\hline RDW & $14.0 \pm 1.3$ & 13.8 (13.2-14.4) & $14.0 \pm 1.3$ & $13.7(13.2-14.4)$ & $14.2 \pm 1.4$ & $13.9(13.3-14.6)$ & 0.152 \\
\hline MPV & $9.0 \pm 1.1$ & $8.9(8.2-9.7)$ & $8.4 \pm 1.1$ & $8.9(8.1-9.7)$ & $9.2 \pm 1.0$ & $9.1(8.4-9.8)$ & 0.097 \\
\hline PLR & $116.2 \pm 49.5$ & $108(84-134)$ & $116.1 \pm 51.0$ & 107 (84-133) & $117.6 \pm 38.0$ & 115 (95-137) & 0.228 \\
\hline NLR & $2.8 \pm 2.4$ & $2.4(1.8-3.2)$ & $2.8 \pm 2.6$ & $2.3(1.8-3.2)$ & $3.1 \pm 1.3$ & $3.0(2.0-3.7)$ & 0.003 \\
\hline Mortality & $26(5.0 \%)$ & & $2(0.4 \%)$ & & 24 (36.4\%) & & $<0.001$ \\
\hline
\end{tabular}

N: Number pf patients, BMI: Body mass index, LDL: Low density lipoprotein RDW: Redcell distribution width, MPV: Mean platelet volume, PLR: Platelet lymphocytes ratio, NLR: Neutrophil lymphocyte ratio

of 24 patients. Patients with and without complications are compared in Table $\mathrm{V}$ according to their preoperative characteristics and laboratory data. Age, preoperative blood glucose level, hemoglobin value, MPV and NLR were associated with the develop- ment of complications $(p<0.001, p=0.046, p=0.005$, $p=0.097$, and $p=0.003$, respectively). However, multivariate analysis of these data using the indicated models showed that only age was an independent predictor of complications $(p<0.001)$ (Table VI). 


\section{DISCUSSION}

In this study, we aimed to evaluate the patients who died or developed complications in the hospital within 30 days after coronary artery bypass surgery in terms of some simple and easy preoperative predictors. Comorbidities and the detailed scoring systems were not evaluated in detail. In the literature, there are publications regarding simple predictors for evaluating postoperative complications and mortality, regardless of the detailed preoperative characteristics of the patients ${ }^{(5-8)}$. However our results showed that none of the preoperative simple parameters were found to be independent predictors, only age was an independent predictor of mortality and complications. It is a well-known fact in the literature that mortality rates increase with aging ${ }^{(9-11)}$.

It is a great challenge to predict outcomes in cardiac surgery procedures. Besides the personal characteristics of each patient, evaluating the severity of the disease is quite complex and far from our current capacity in cardiac surgery. EuroSCORE system is one of the frequently used and most specific assessment for heart surgery. Age, gender and comorbidities such as renal, pulmonary pathologies, arteriopathy, endocarditis and diabetes are scored as factors related to the patient within the EuroSCORE system.

Body mass index is often considered as a factor that increases early postoperative complications but does not affect mortality ${ }^{(12,13)}$. In our study, BMI was not associated with mortality or postoperative complications. The effect of metabolic syndrome on postoperative outcomes of patients undergoing surgery is another subject of interest. The incidence of MS, which is $23-28 \%$ in the general population ${ }^{(14,15)}$, is close to $46 \%$ in cardiac surgery patients ${ }^{(16,17)}$. In our study, in which we received the data of isolated coronary artery bypass surgery, the incidence of MS was $51.4 \%$.

Also, our results have shown that the metabolic syndrome has no significant effect on mortality and adverse events ( $p=0.286, p=0.279)$. Obesity and diabetes are diagnostic complexes that are intertwined with MS. Almost one third/half of those who have been diagnosed with MS and have undergone CABG surgery are diabetic ${ }^{(16,17)}$. In our patient population,
$85 \%$ of the patients with MS were diabetic. MS appears to be an independent predictor of mortality after CABG surgery ${ }^{(18,19)}$. However, it has been suggested that MS does not affect mortality in diabetic patients, but its incidence increases in non-diabetic patients ${ }^{(17)}$. In our study, the diagnosis of MS in was not found to be predictive of postoperative complications and mortality in our patient population. Similar to our conclusion, there are studies that have not found any association between mortality and MS ${ }^{(20,21)}$. Mean preoperative fasting blood glucose was found to be $134 \pm 141 \mathrm{mg} \mathrm{dL}^{-1}$ in patients with and without mortality and $133 \pm 144 \mathrm{mg} \mathrm{dL}^{-1}$ in patients with and without complication. In patients who were prepared for operation under elective conditions, blood glucose values were closely observed and no significant difference was found.

It is common practice in the literature to suggest preoperative hematologic parameters predict mortality and complications in the search for practical and easy methods. It is emphasized that the preoperative diagnosis of anemia is strongly associated with mortality ${ }^{(8,22)}$. Hemoglobin values below $13 \mathrm{~g} \mathrm{dL}^{-1}$, which is accepted as a diagnostic criterion for anemia, were not found in our patients. In multivariate analysis, the hemoglobin value was not predictive. In terms of another marker, high inflammatory mediators in circulation predispose the patients to the development of cardiovascular disease (23). MPV, RDW, NLR, PLR from hematological parameters are easily measurable in this respect. MPV is directly related to the aggregation function of platelets, MPV levels increase in acute coronary syndromes and diseases that increase cardiovascular risk $(6,7,24)$. Similarly, RDW has been shown to vary in different clinical conditions such as stroke, myocardial infarction, atrial fibrillation and heart failure, and it predicts mortality and morbidity in cardiac surgery ${ }^{(5,6)}$. However, no significant changes in MPV and RDW were observed in patients with mortality and complications. Similarly, PLR and NLR values did not show any predictive impact. In this study, the number of our patients is lower than in the literature. This may be the reason why we achieved these results. This may be because in-hospital mortality and complications are more closely related to intraoperative variables, as well. Gomes et al. ${ }^{(25)}$ studied 1458 patients to present a new prognostic score. They found that 
E. Balcı ve ark., In-Hospital Mortality and Complications Following Coronary Artery Bypass Surgery; is it Possible to Predict with Preoperative Values?

postoperative first day factors such as inotropic use, duration of mechanical ventilation longer than 12 hours, and $\mathrm{PO}_{2} / \mathrm{FiO}_{2}$ ratio were associated with mortality as well as CPB duration of 180 minutes and more. According to another study, intraoperative factors such as inexperienced surgeons, longer CPB time, re-do $C P B$, intra-aortic balloon usage, are known to improve preoperative risk estimation (26). Lesser surgeon experience and low-volume cardiac surgery centers are said to be associated with mortality ${ }^{(27)}$. The emergence of a new $Q$ wave, highly effective myocardial protection during CPB, the types of grafts used (internal mammary artery $\&$ saphenous vein), the diameter of the coronary arteries, the quality of anastomosis, bleeding and transfusion, as well as many other intraoperative factors are found to be related with postoperative outcomes. In our study, MACE, ARF and bleeding/tamponade complications were significantly higher in exited patients (Table III). MACE is one of the most common causes of morbidity and mortality after CABG surgery ${ }^{(28)}$. This demonstrates the importance of intraoperative variables such as the quality of coronary artery anastomoses or myocardial protection. In our study, the euroSCOREs, preoperative organ function indicators, comorbidities of the patients, various intraoperative variables such as CPB duration, number of anastomoses, transfusion of blood products, which may affect the results, were not observed. We could have more comprehensive results if we had more detailed pre-, intra-, and postoperative patient information, but this was not possible.

As a result of this study, it may not possible to predict mortality and complications after CABG surgery, only with preoperative laboratory values. In order to achieve ideal results, comprehensive intraoperative and surgical data and early postoperative data should be taken into consideration.

\section{Acknowledgments}

There is not any financial support or sponsorship in current study.

\section{REFERENCES}

1. Shahian DM, O'Brien SM, Filardo G, et al. The Society of Thoracic Surgeons 2008 Cardiac Surgery Risk Models: Part 1-Coronary Artery Bypass Grafting Surgery. Ann Thorac Surg [Internet]. 2009;88:S2-22.
Available from: http://dx.doi.org/10.1016/j.athoracsur.2009.05.053

2. Sanagou M, Wolfe R, Forbes A, Reid CM. Hospital-level associations with 30-day patient mortality after cardiac surgery: A tutorial on the application and interpretation of marginal and multilevel logistic regression. BMC Med Res Methodol [Internet]. 2012;12:28. http://www.biomedcentral.com/1471-2288/12/28

3. O' Brien SM, Shahian DM, Filardo G, et al. The Society of Thoracic Surgeons 2008 Cardiac Surgery Risk Models: Part 2 - Isolated Valve Surgery. Ann Thorac Surg 2009;88:23-42. http://doi.org/10.1016/j.athorac-sur.2009.05.056

4. Kajimoto K, Miyauchi K, Kasai T, et al. Metabolic syndrome is an independent risk factor for stroke and acute renal failure after coronary artery bypass grafting. J Thorac Cardiovasc Surg. 2009;137:658-63. http://doi.org/10.1016/j.jtcvs. 2008.11.043

5. Warwick R, Mediratta N, Shaw M, et al. Red cell distribution width and coronary artery bypass surgery. Eur J Cardio-thoracic Surg. 2013;43:1165-9. https://doi.org/10.1093/ejcts/ezs609

6. Aydınlı B, Demir A, Güçlü ÇY, et al. Hematological predictors and clinical outcomes in cardiac surgery. J Anesth. 2016;30:770-8. https://doi.org/10.1007/s00540-016-2197-y

7. Chu SG, Becker RC, Berger PB, et al. Mean platelet volume as a predictor of cardiovascular risk: A systematic review and meta-analysis. J Thromb Haemost. 2010;8:148-56.

https://doi.org/10.1111/j.1538-7836.2009.03584.x

8. Miceli A, Romeo F, Glauber M, de Siena PM, Caputo M, Angelini GD. Preoperative anemia increases mortality and postoperative morbidity after cardiac surgery. J Cardiothorac Surg. 2014;9:1-7. https://doi.org/10.1186/1749-8090-9-137

9. Hannan EL, Burke J. Effect of age on mortality in coronary artery bypass surgery in New York, 1991-1992. Am Heart J. 1994;128:1184-91. https://doi.org/10.1016/0002-8703(94)90750-1

10. Naughton C, Feneck RO, Roxburgh J. Early and late predictors of mortality following on-pump coronary artery bypass graft surgery in the elderly as compared to a younger population. Eur J Cardio-thoracic Surg. 2009;36:621-7. https://doi.org/10.1016/j.ejcts.2009.04.066

11. Hansen PW, Gislason GH, Jørgensen ME, et al. Influence of age on perioperative major adverse cardiovascular events and mortality risks in elective non-cardiac surgery. Eur J Intern Med. 2016;35:55-9. http://dx.doi.org/10.1016/j.ejim.2016.05.028

12. Yap $\mathrm{CH}$, Mohajeri M, Yii M. Obesity and early complications after cardiac surgery. Med J Aust. 2007;186:350-4.

13. Demir A, Aydinli B, Güçlü ÇY, et al. Obesity and postoperative early complications in open heart surgery. J Anesth. 2012;26:702-10. https://doi.org/10.1007/s00540-012-1393-7

14. Guize L, Thomas F, Pannier B, Bean K, Jego B, Benetos A. All-cause mortality associated with specific combinations of the metabolic syndrome according to recent definitions. Diabetes Care. 2007;30:2381-7. https://doi.org/10.2337/dc07-0186

15. Moebus S, Balijepalli C, Lösch C, et al. Age- and sex- 
specific prevalence and ten-year risk for cardiovascular disease of all 16 risk factor combinations of the metabolic syndrome - A cross-sectional study. Cardiovasc Diabetol. 2010;9:1-12. https://doi.org/10.1186/1475-2840-9-34

16. Echahidi N, Pibarot P, Després JP, et al. Metabolic Syndrome Increases Operative Mortality in Patients Undergoing Coronary Artery Bypass Grafting Surgery. J Am Coll Cardiol. 2007;50:843-51. https://doi.org/10.1016/j.jacc.2007.04.075

17. Kajimoto K, Kasai T, Miyauchi K, et al. Metabolic syndrome predicts 10 -year mortality in non-diabetic patients following coronary artery bypass surgery. Circ J. 2008;72:1481-6. https://doi.org/10.1253/circj.CJ-07-0928

18. Eckel R, Grundy S, Zimmet P. The metabolic syndrome. Lancet. 2005;365:1415-28. https://doi.org/10.1016/S0140-6736(05)66378-7

19. Isomaa B. A major health hazard: Metabolic syndrome. Life Sci. 2003;73:2395-411. https://doi.org/10.1016/S0024-3205(03)00646-5

20. Ozyazicioglu A, Yalcinkaya S, Vural AH, Yumun G, Bozkurt Ö. Effects of metabolic syndrome on early mortality and morbidity in coronary artery bypass graft patients. J Int Med Res. 2010;38:202-7. https://doi.org/10.1177/147323001003800123

21. Özkan S, Özdemir F, Uğur O, et al. The effects of the metabolic syndrome on coronary artery bypass grafting surgery. Cardiovasc J Afr. 2017;28:48-56. https://doi.org/10.5830/CVJA-2016-056

22. Scrascia G, Guida P, Caparrotti SM, et al. Incremental value of anemia in cardiac surgical risk prediction with the European system for cardiac operative risk evaluation (EuroSCORE) II model. Ann Thorac Surg.
2014:98:869-75

http://dx.doi.org/10.1016/j.athoracsur.2014.04.124

23. Park BJ, Shim JY, Lee HR, Jung DH, Lee JH, Lee YJ. The relationship of platelet count, mean platelet volume with metabolic syndrome according to the criteria of the American Association of Clinical Endocrinologists: A focus on gender differences. Platelets. 2012;23:4550.

https://doi.org/10.3109/09537104.2011.589014

24. Shah B, Sha D, Xie D, Mohler ER, Berger JS. The relationship between diabetes, metabolic syndrome, and platelet activity as measured by mean platelet volume: The National Health and Nutrition Examination Survey, 1999-2004. Diabetes Care. 2012;35:1074-8. https://doi.org/10.2337/dc11-1724

25. Gomes R, Tura B, Mendonca Filho H. A first postoperative day predictive score of mortality for cardiac surgery.le. Ann Thorac Cardiovasc Surg. 2007;13:159-64.

26. Stoica SC, Sharples LD, Ahmed I, Roques F, Large SR, Nashef SAM. Preoperative risk prediction and intraoperative events in cardiac surgery. Eur J Cardio-thoracic Surg. 2002;21:41-6.

https://doi.org/10.1016/S1010-7940(01)01077-6

27. Rosenthal G, Vaughan Sarrazin M, Hannan E. In-hospital mortality following coronary artery bypass graft surgery in Veterans Health Administration and private sector hospitals. Med Care. 2003;41:522-35. https://doi.org/10.1097/01.MLR.0000053231.70549.2D

28. Herman $\mathrm{CR}$, Buth $\mathrm{KJ}$, Légaré JF, Levy $A R$, Baskett R. Development of a predictive model for major adverse cardiac events in a coronary artery bypass and valve population. J Cardiothorac Surg. 2013;8:1-6. https://doi.org/10.1186/1749-8090-8-177 